\title{
Social media usage by teen segmented commercial private radio in Bandung
}

\author{
Martha Tri Lestari ${ }^{1, *}$, and Hadi Purnama ${ }^{1}$ \\ ${ }^{1}$ Communication Science Department, Communication\& Business Faculty, Telkom University
}

\begin{abstract}
Radio is one of mass media which functions to inform, to educate, to entertain and to influence. In Indonesia, private commercial broadcast radios are the biggest in numbers with more than 700 radio stations throughout indonesia. Some of the private commmercial radio stations select audience segmentation of young people or teenagers. This is due to fact that numbers of young people dominate the whole population. Social media nowadays has become a primary need for most of its users, especially young people. The usage of social media as a tool in virtual social interaction, has also been used by many radio stations, especially whose target audience are teenagers. The usage of social media by teen segmented radio stations is not only for on-air activities, but also to support off-air activities. How the use of social media by teen segmented radio stations in Bandung, to support on-air and off-air activities, is the focus of this research. Through qualitative research with descriptive method, it is hoped to describe more comprehensively about the usage of social media by teen segmented private radio stations in Bandung.
\end{abstract}

\section{Introduction}

Media is not as traditional as before, conventional mass media also has limited time release or certain schedule which makes it difficult for the audience to access information at any time. The weakness of media such as limitation of place, time, or pages, can be covered by online media which is accessible anytime, anywhere [1]. This time, media has transformed into a 'new media' technology, known as social media.

Social media is the media we use to be social. The story is in the tactics of each of the hundreds of technologies, all of the tools that are avilable for you to connect with your customers and prospects, and the strategies necessary to use these tactics and tools effectively [2].

Industries which has developed or are developing nowadays rely on publication as one way to publish their companies, likewise media industry such as radio. Publication is one element of Public Relations. Public Relations itself is part of Integrated Marketing Communication. Rhenald Kasali in manajemen Public Relations, Konsep dan Aplikasinya di Indonesia in [3] said:

\footnotetext{
* Corresponding author: martha.djamil@gmail.com
} 
"management function in public relations concept is aimed to create and develop best perception of an institution, organisation,company, or their products to people segmented,which activities have instant or uninstant effect towareds the future of organization, company, or product."

Public Relations activities is closely related to public opinion building and behaviour change of the society [4]. Furthermore, according to [3] function and task of Public Relations are publicity, publication, advertising, promotion, press relations, etc . through description above, writer can conclude that public relations function in an organization or company are important because it can help to support company's activity in building good relations and communication with its internal and external publics.

Radio is a creation of technology development which voice is transmitted together through radio wave in the air. [6] Bandung has many developing and developed commercial radio stations. On this opportunity writer intended to do a research to commercial radio stations which are Zora Radio, 99'ers Radio, OZ Radio and Ardan Radio. Writer selected these four teen-segmented radio stations based on several considerations such as internet penetration scale for Indonesian citizen is now more than 30 persen of total Indonesian. A survey conducted by Nielsen with respondents aged over 13 year old between March 2013 through May 2013 showed the smartphones penetration in developing countries in Asia Pasific has increased. The focus of this research is based on writer's curiosity in how the usage of social media by teenage-segmented private commercial radio stations in Bandung in supporting Public Relations activities (Promotion and Publication) as well as on-air or offair radio programs.

\section{Research methodology}

This research used qualitative research methodology. Jane Richie in [7] explained that qualitative research is an effort to display social world, and its perspective in world, from concept, behaviour, perception, and problems of studied humans studied. Qualitative research is specifically targeted in the use of facts. This research studies problems in society and how to behave socially in certain society or conditions, including relationship, activities, attitudes, point of views, and ongoing process and influence in a phenomenon.

\subsection{Population and sampling}

The population about this research are informans who know about social media function in their radio station. In this research we invited informans from 4 (four) teen-segmented radio stations which is most popular radio station in Bandung-Indonesia. There are Director\&Marketing Manager from Zora Radio, Station Manager 99'ers Radio, Digital Communication unit from Ardan and OZ Radio.

\section{Result and discussion}

In result of this research, which 4 (four) teen-segmented radio stations in Bandung were the research's subject, researcher has summarized, studied according to theory used and analized results from questions in Focus Group Discussion (FGD) and the answers packaged based on questions list divided into 3 (three) discussion stages and answers form each informan key as representative of each radio stations. The result of FGD data processing: 


\subsection{Question stage I}

On segment I in this research questions given are still on the basic stage such as since when do they use social media, the reasons or considerations in using social media, obstacles in using social media, which social media used and which are the top priorities to be used by the radio stations. The results are:

\subsubsection{Zora Radio}

The answered that represented by Director and Marketing Manager Radio Zora, it is known that the using of social media in Zora FM started to be active when Zora radio switched its segment into teenagers listeners. They have used the internet for quite a long time, but communication using media social internally and externally has resulted in excalating interactions with listeners, users and even with internal staff of zora. The background why Zora radio uses social media is the need of client/costumers. The population of society using gadgets especially smartphones is so high,they even use multi gadgets. Media convergent era was one of the main reasons why social media is needed by teen-segmented radio stations. Obstacle found in earlier time in using social media was the human resources. Back then, it was difficult to find a rightful human resource to be responsible in media social division. Every social media has its own different characteristics because social media is something fluid and flowing, and social media age shorter time by time, social media content could be an obstacle in using social media.

\subsubsection{9' ers Radio}

99'ers Radio started to maintain its streaming application in early 2000. Nevertheless, he could not specify when exactly they used social media. At first, they used Facebook, but not for long, only lasted around one year from 2009-2010. They use Twitter more than other social medias. The website was not functioned in rising interactions until 2011, since they still interacted by sms, on air broadcast, etc. The background of using social media was based on the need from bottom to the top, meaning the need of market to the need of top management of the radio itself. Listeners' trends, the need of interactions between users/clients, listeners, and also radio employees have become one of the reasons in using social media, based on survey conducted by 99 ers radio on social media usage, it can be said that social media usage was more advantageous than conventional media usage because it was more 'low cost', even 'no cost', then market needs will be fulfilled. The usage of social media today has become costumers behaviour and also can be a tool to support 99ers in conducting public relations activity. 99'ers Radio has a goal to "follow on to device" which means that $70 \%$ of the consumers using gadgets can use 99ers mobile application, and the last one is client demand; so the usage of social media is relevamt to the clients commercial needs. Obstacles in social media usage is almost the same with others, which is on finding the rightful human resource. At this time, 99'ers radio only has 2 staffs (webmaster and pic socmed) where they both have different objectives towards socialo media which made lack of coordination between the two.

\subsubsection{Oz Radio}

OZ Radio began to use the internet around the year 2000, then continued in 2005 by establishing a website. The usage of social media started with the released of facebook in 2006. In the beginning, they used personal account, not a fanpage. In last 2006 or early 2007 OZ Radio created official facebook and twitter accounts baring the radio's brand 
name. According to OZ Radio's social media writer and content media editor, the backgorund of using social media was because it was the demand of their consumers (listeners). For example, listeners can find out about the song's title or the singer by twitter. Beside that consumers need, the usage of social media has become a main point asked by clients (advertiser, agency, and listeners). The obstacle in using social media according to informan of $\mathrm{OZ}$ Radio is the lack of human resources. They only have 2 persons responsible for social media usage and it is not adequate. He stated that ideally, 1 account should be managed by 1 person. This lack of human resources resulted in non-optimum usage of social media by the radio.

\subsubsection{Ardan Radio}

Ardan Radio has used the internet since the 2000's by using a website without online interaction with its listeners. Around 2005 through 2008, Ardan has used social media such as Facebook, Twitter but not optimally. The background of using the social media as communication and interaction tool was after seeing the market has moved towards digital, consumers, buyers, users, have become visual users and could also be called "gadget freak". It could be concluded that this digital era has tunerd into costumers trend. The obstacle in using social media focused in human resources. Ardan Radio was lack of human resources to maintain the websites. At this time, there is only 1 person who handles 4 websites of Ardan Group. Now Ardan Radio has its own division in handling social media usage which is Digital Communication Division while it is still difficult to find competent person for the position in the division. According to head digital communication Ardan radio who is the informan in this research, ideally this division should have around 6 persons / human resourcers.

\subsection{Question Stage II}

On stage II of the FGD, questions given to the informan were more specific. They were asked about social media usages such as the strength, weakness, and opprtunity in using social media. Special strategy in using social media, which unit handles the authority to use the social media, the advantages of using social media and how the social media function in building the radio's brand image. The results are:

\subsubsection{Zora Radio}

According to informan of Zora Radio, he stated that the strength of social media has to have visual power in each account. Just like in twitter and instagram, consumers will be more attracted to see them if the accounts are rich in visualization. PR and Promotion division is the one responsibles for the media social usage. The usage of social media in zora radio is to socialise, podcast, lowcost broadcast media which can also be used to analyze Zora's listeners' characteristics such as listeners profiling, which is advantageous in program or content selling to advertisers.

\subsubsection{9' ers Radio}

According to informan of 99'ers Radio who is the station manager, there are different strategies in using social media. Social media is one functional tool to support sales marketing and public relations programs as well as on air and off air programs (sales oriented, program oriented). Monitoring the usage of social media is really needed because it can give advantage in rising numbers of listeners by maintaining the social media 
content. Participation from the radio internal is also important, for example in creating more lively creative campaign. The power of social media has to cope with the listeners since nowadays they are the visual generation where social media has becoma the main commodity in interaction. This division is under PR and Promotions unit.

\subsubsection{Oz Radio}

At this time, division responsible in handling social media usage is On Air program division. Previously, it was handled under PR and Promotions. The strength of social media in OZ radio is because it is always put forward on air content such as commerciallike content, built in between on-air programs' content. The opportunity in using social media related is so big. That is the reason why the usage has to be put into deep attention. For instance, the content in social media has to include a graphic designer in creating the posters. Furthermore, social media can become a media shorcut to interact with talents needed.

\subsubsection{Ardan Radio}

Ardan Radio has just established new division/unit related to media social handling, i.e Digital Communication Unit. According to Head of Digital Communication it is extremely important that the existing units integrate in supporting the usage of social media. It is because as we can see from the weakness of not having adequate competent personnels, the integration of units would be a good solution to the problem in social media usage. The opportunity lies ahead in social media usage can be seen from on air and off air sides, for examples the rising numbers of advertising clients. The special strategy is the "do and goals" of the social media have to be balanced. Besides that, Ardan is trying to collaborate between analog radio with the development nowadays which is 4 Os (On Air, Off Air, On Mobile and On Light) while the integration of all those services is being conducted so it is overlapping.

\subsection{Question Stage III}

On this stage III of FGD the questions is more focused to the outside of the usage of social media like to develop On Air or Off Air program, human resuources allocation, and financing allocation to manage social media, pengelolaan,influence towards society's loyalty and media prediction habit of each radio station.

\subsubsection{Zora Radio}

Social media has an important contribution to radio programs improvements, one way is by profiling study of its listeners. How the social behaviour ipof the listeners is another important element to support the improvements of On Air or Off Air programs.

From the profiling study, the media habit of Zora Radio can be mapped. But at this time, media habit analysis has not been done because it is still considered a short period of time since zora Radio changed its segmentation towards teenage listeners.

\subsubsection{9 'ers Radio}

Media Habit can be predicted but prediction will not be too far in the future because changes will influence listeners' media habit. Consumers who actually are listeners have a vision that radio is a conventional media. With the vast changing of social media in the last 
4 years, prediction culd not be made too far, so 99ers would only be playing in what's up to date.

\subsubsection{Oz Radio}

Social media has an important contribution with maximum usage. Media habit prediction for OZ Radio besides Ac Nielsen which has online research, OZ has another way to do the analysis by conducting depth interview.

\subsubsection{Ardan Radio}

Social media has a high contribution, especially in changing media habit of the listeners. There are changes from previous radio activities into these days activities when technology has developed highly. For instance, high interests in podcast or selfie pics which are now trending today, were some of several behaviours of the listeners that should be supported by the right contents served by Ardan radio. Media habit of Ardan listeners are more about how to change the behaviour of old time era listeners into digital era or convergent media era like today.

\section{Conclusion}

The four of radio stations have and use active social media in communicating and interacting to conduct activities related to promotions or publications activities which are one of the elements of Public Relations activities. Strategy and usage in each radio station is different, but basically each station focuses on content. Visualization dimension is one of the strategies in using the social media. And they actually used the social media for doing some PR Activities such as cyber PR, sponsorship, companies identity, direct communications, publicity, CSR, special events and media inggriya [5]. Some of the radio stations use media habit analysis with indepth interview research on listeners/clients and studi profiling as well. As for media habit prediction, it can not be forseen too far in the future due to the rapid development of technology which will influence the usage of the social media itself. Suggestions which can be offered to the four stations is to allocate financial fund provided by the company, relating to the responsible unit of social media usage. Therefore the main key is to search for human resources who are creative, innovative and technology literate that can also cope with segmentation, targeting and also positioning of each station in accordance to keep on existing as radio publicity media for their audience/listeners which are not only in bandung area but also has spread to other urban cities through streaming application on internet media.

\section{References}

1. M. Romli, Asep Syamsul. Jurnalistik Online : Panduan Praktis Mengelola Media Online. Bandung : Nuansa Cendikia.34.(2012)

2. L. Safko. The Social Media Bible. Tactics, Tools, And Strategies For Business Success. John Wiley\&Sons Inc 2nd Edition. 3. (2010)

3. R. Rosady. Manajemen Public Relations \& Media Komunikasi.Jakarta : PT Rajagrafindo Persada.11. (2008)

4. F. Nova. Crisis Public Relations (Bagaimana PR Menangani Krisis Perusahaan).Jakarta : Grasindo. 38. (2009). 
5. P. Wahyuni . Special Event. Alternatif Jitu Membidik Pasar.xxxi (2013)

6. I. Astuti Santi. . Jurnalisme Radio. Simbiosa Rekatama Media. (2008)

7. J. Moleong, Lexy. Metode Penelitian Kualitatif.6. (2002) 